\title{
SUPPORTING MATERIASL
}

\author{
Polymer-Enzyme Conjugates can Self-Assemble at Oil/Water Interfaces and \\ Effect Interfacial Biotransformations \\ Guangyu Zhu, Ping Wang* \\ Department of Chemical Engineering, The University of Akron, Akron, OH 44325-3906 \\ Email: wangp@uakron.edu
}

\section{Materials:}

$\alpha$-Chymotrypsin (from bovine pancreas), $\beta$-galactosidase (from Aspergillus Oryzae) $\mathrm{N}, \mathrm{N}$-dimethylformamide (DMF), methylene chloride (dichloromethane), chloroform, n-succinylala-ala-pro-phe p-nitroanilide (SAAPPN), 4-dimethylaminopyridine (DMAP), 4methylumbelliferyl p-trimethyl-ammonium cinnamate chloride (4-MUTMAC), poly(ethylene oxide) (PEO) of Mw 10,000 Da, and potassium sodium-tatrate were purchased from Sigma (St. Louis, MO). Bradford Coomassie protein assay reagent and BSA protein standard were obtained from Bio-Rad laboratories (Hercules, CA). Styrene was obtained from EM (Gibbstown, NJ). 2,2'-azobis [2-methyl-N(2-hydroxyethyl) propionamide] (VA-086) was provided by Wako Pure Chemical Industries, Ltd. (Osaka, Japan). Toluene was obtained from J.T. Baker (Phillipsburg, NJ). 4-Nitrophenyl chloroformate (NPC), epichlorohydrin, 1-hexanol, bathocuproinedisulfonic acid salt, and $\beta$-D-lactose (contains 25-30\% $\alpha$-D-lactose) were obtained from Aldrich (Milwaukee, WI). $\mathrm{CuSO}_{4}\left(5 \mathrm{H}_{2} \mathrm{O}\right)$ and $\mathrm{NaOH}$ were purchased from VWR Sci. (PA). Ascorbic acid was purchased from Mallinckrodt, KY. Poly(lactic acid) (PLA) of Mw 100,000 Da was purchased from Polysciences, Inc. All the other chemicals were of the highest purity available.

\section{Polymer-enzyme conjugation:}

Scheme 1 depicts the chemical routes for the conjugation process. Details for each step are given in the following: (1) Polymer preparation. Polystyrene (PS) was first synthesized via free radical polymerization initiated by VA-086, which possesses a hydroxyl group. The polymerization was conducted in a $20 \mathrm{ml}$ scintillation vial under $\mathrm{N}_{2}$. In a typical procedure, $0.1 \mathrm{~g}$ of VA-086 was first dissolved into $4 \mathrm{ml}$ DMF. The solution was then mixed with $5 \mathrm{ml}$ styrene and $1 \mathrm{ml}$ toluene. The vial was purged with $\mathrm{N}_{2}$ and incubated in water bath at $72^{\circ} \mathrm{C}$ for $24 \mathrm{~h}$. The reaction was stopped via pouring the reaction solution into $50 \mathrm{ml}$ of methanol to precipitate PS. The precipitate was further washed by $25 \mathrm{ml}$ methanol for at least 3 times to remove unreacted styrene and initiator. The molecular weight of PS was measured by GPC using a PLgel MIXED column (Polymer Laboratories, MA) with chloroform as the mobile phase. PS was then functionalized using NPC. Typically, $0.5 \mathrm{~g}$ PS and $12.2 \mathrm{mg}$ DMAP were dissolved in $8 \mathrm{ml}$ toluene and cooled to $4^{\circ} \mathrm{C}$ in a $20 \mathrm{ml}$ scintillation vial. The reaction was initiated by adding $2 \mathrm{ml}$ of $0.01 \mathrm{M}$ NPC (in anhydrous methylene chloride) under stirring. The reaction was allowed to last $5 \mathrm{~h}$ before centrifugation to remove the precipitate of 4-dimethylaminopyridine hydrochloride. The supernatant containing PS attached with nitrophenyl ending groups was precipitated and washed with methanol. The final product was dried by blowing $\mathrm{N}_{2}$. (2) Polymer-protein conjugation. Typically $0.1 \mathrm{~g}$ NPC activated PS (Mw 8000) was dissolved in $3 \mathrm{ml}$ toluene, and was mixed with $3 \mathrm{ml}$ buffer $(\mathrm{pH} 6.1$ for $\beta$-galactosidase and $\mathrm{pH} 9.0$ for $\alpha$ chymotrypsin) containing $3 \mathrm{mg} / \mathrm{ml}$ protein under stirring for $8 \mathrm{~h}$. The reaction solution was centrifuged for phase separation, and the resulted polymer-enzyme conjugate was purified by 
changing the aqueous phase repeatedly with fresh buffer solution to remove unmodified enzyme till no protein was detectable in the solution, followed by changing the organic phase with pure toluene to remove unreacted polymer for at least 5 times. The product was finally recovered from the interface area of the mixture by removing bulk phase solutions followed by drying. The protein content in the aqueous solution was monitored by protein assay method before and after modification reaction. Up to $45 \%$ of the protein was transformed into polymer-enzyme conjugate based on mass balance calculations. GPC analysis of the conjugate showed a peak that clearly shifted away from that of the PS modifier.

Commercially available PEO was activated using 4-nitrophenyl chloroformate and was then conjugated with enzymes following the same procedures as PS conjugation. PLA was activated using epichlorohydrin $(\mathrm{ECH})$ then was conjugated with enzymes through similar procedures. The PLA activation was performed at the following conditions: PLA $(0.45 \mathrm{~g})$ was dissolved in $5 \mathrm{ml}$ chloroform and then mixed with $2 \mathrm{ml} \mathrm{ECH}$. The solution was stirred for $7 \mathrm{~h} \mathrm{at}$ room temperature, and then refluxed at $65^{\circ} \mathrm{C}$ for $20 \mathrm{~min}$. The product was recovered by evaporating the solvent and remaining $\mathrm{ECH}$.

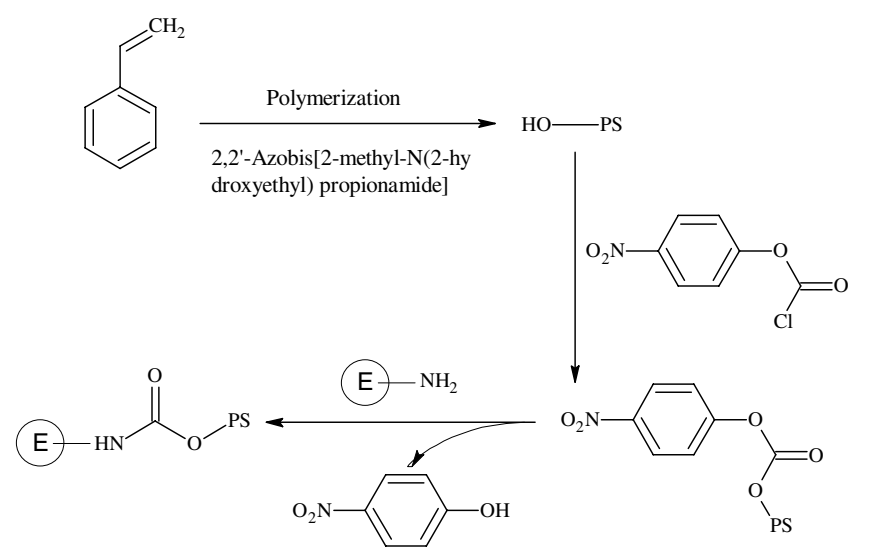

Scheme 1. Chemical route for the preparation of polymer-enzyme conjugates.

\section{Interfacial transgalactosylation reaction:}

Interfacial transgalactosylation reactions were carried out in a reactor with an inner diameter of $13.2 \mathrm{~cm}$. The volumes of aqueous and organic phases were 350 and $100 \mathrm{ml}$, respectively. 1-Hexanol was dissolved in toluene (40\%-v/v, $3.2 \mathrm{M})$ and lactose was contained in aqueous phase with concentrations ranged from 0.05 to $0.7 \mathrm{M}$. Aliquots of $500 \mu \mathrm{l}$ of organic phase were withdrawn periodically during the reaction for HPLC analysis. The product hexylgalactoside was recovered by evporating the solvent and reamining hexanol, and was then dissolved in $250 \mu \mathrm{l}$ HPLC mobile phase solvent (which consisted of $80 \%$ acetonitritel and $20 \%$ water) for analysis on a Shimadzu 10VP system euqipped with a $3.9 \times 300 \mathrm{~mm}$ Carbohydrate Analysis column from Waters. Figure 1 shows the ${ }^{13} \mathrm{C}$ NMR spectrum of hexyl-galactoside (CD $\left.{ }_{3} \mathrm{OD}, 300 \mathrm{MHz}\right)$ : $\delta 69.142$ (C-1'), 31.720 (C-2'), 25.657 (C-3'), 29.652 (C-4'), 22.538 (C-5'), 13.231 (C-6'), 103.844 (C-1, $\beta$-bond), 71.411 (C-2), 73.896 (C-3), 69.683 (C-4), 75.433 (C-5), 61.303(C-6).

\section{Stability tests:}

Glass vials of inner diameter of $5 \mathrm{~cm}$ containing native or PS-GL, in the presence of $4 \mathrm{ml}$ $\mathrm{pH} 4.5$ acetate buffer and $2.6 \mathrm{ml}$ toluene, were incubated without shaking in water bath at $55^{\circ} \mathrm{C}$. The concentration of native GL in the buffer phase was $0.5 \mathrm{mg} / \mathrm{ml}$, while PS-GL was incubated with an amount of $0.2 \mathrm{mg}$ for each vial. Periodically, vials were taken out from the water bath for 
activity tests. The activity tests were initiated by adding $1.6 \mathrm{ml}$ hexanol to the organic phase and solid lactose to the aqueous phase (initial lactose concentration was controlled at $0.7 \mathrm{M}$ ). The vials were shaken at $200 \mathrm{rpm}$ at room temperature and samples were taken from organic phase for product analysis after phase separation. The relative catalytic activities were obtained by taking the activities of the enzymes in the same way before incubating as 1 .

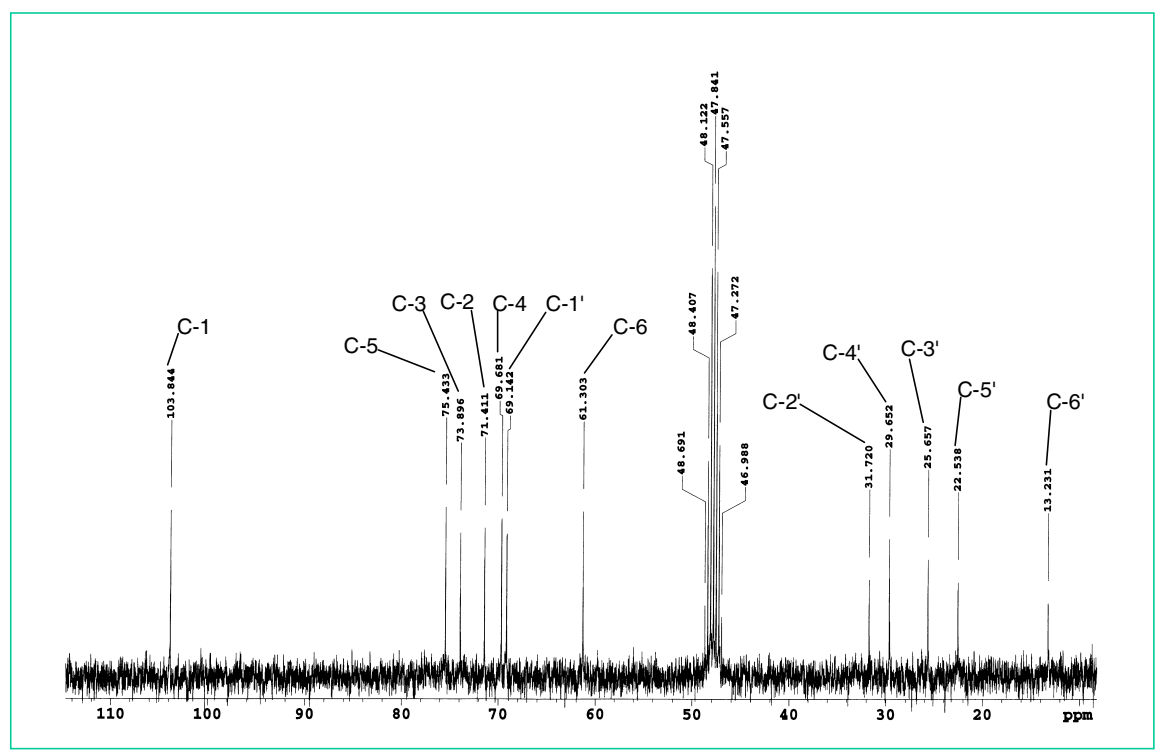

Figure $1{ }^{13} \mathrm{C}$ NMR spectrum of hexyl-galactoside

\section{Effect of lactose concentration on transgalactosylation reaction rate:}

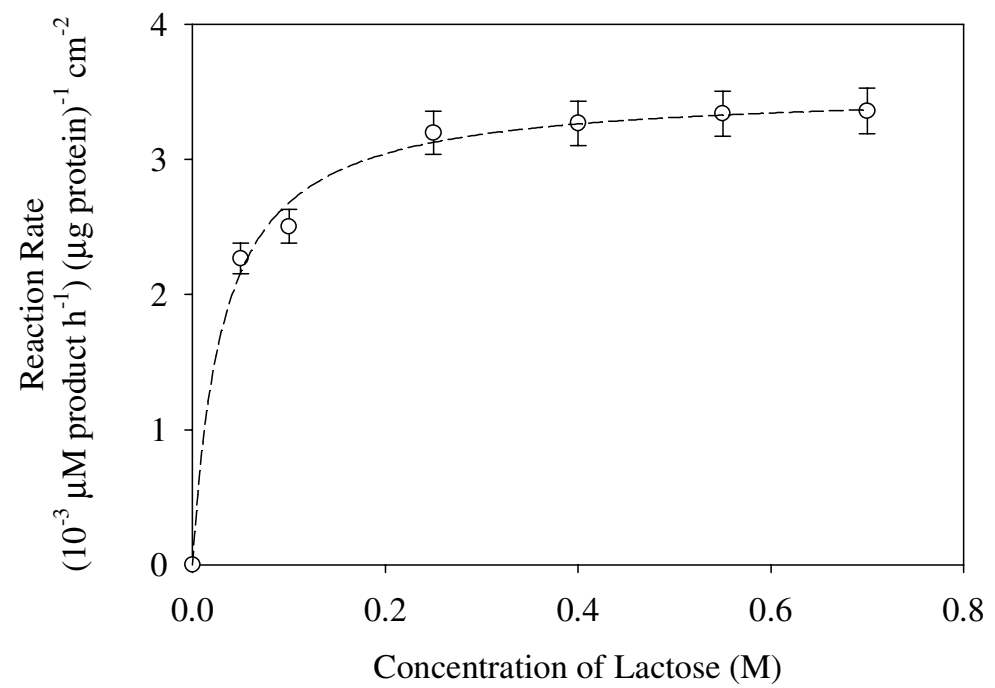

Figure 2 Effect of substrate concentration on the transgalactosylation reaction rate. Interfacial enzyme concentration was $3.5 \mu \mathrm{g}$ protein $/ \mathrm{cm}^{2}$. Fitting with the Michaelis-Menten model led to apparent kinetic parameters as $K_{M}=0.025 \mathrm{M}$ and $v_{\max }=3.4 \times 10^{-3}\left(\mu \mathrm{M}\right.$ product) $\mathrm{h}^{-1}(\mu \mathrm{g} \text { protein })^{-1}$ $\mathrm{cm}^{-2}$. 